\title{
Program Inovar-Auto, Initiatives toward Innovation and Competitiveness in the Automotive Sector in Brazil
}

\author{
Renato Perrotta, Oduvaldo Vendrametto, Rodrigo Franco Gonçalves, Adilson Rocha, \\ and Jorge Monteiro Junior \\ UNIP - Paulista Universtiy, Graduate Program in Production Engineering, \\ Rua Dr. Bacelar, 1212, São Paulo, Brazil
}

\begin{abstract}
This paper aims having an understanding of the actual scenario of loss of competitiveness of the Brazilian industrialized goods, in specific of the automotive sector that has been suffered effects since global financial crisis of 2008. The paper is an exploratory research and seeks having overview of the Program "Inovar-Auto", a new regulatory policy for the automotive sector, that became decree number 7819 published in $3^{\text {rd }}$ of October of 2012. With the program, it is observed opportunities and counterpart toward actions of innovation, competitiveness and sustainability of the sector in Brazil.
\end{abstract}

Keywords: Innovation in developing countries, competitiveness, industry tax benefits.

\section{$1 \quad$ Introduction}

The global financial crisis of 2008 has put in evidence the technological and competitive brittleness of the vehicles produced in Brazil. The trade balance of the sector, formerly positive, became adverse as from 2008, which can be observed in the Table 1.

Aware of the situation, authorities decided to introduce the program "Inovar-Auto", a set of policies that create tax reliefs to car manufactures, who decide to invest in the local production and in the development of the whole productive chain [2] [3].

Table 1. Trade Balance - Brazilian Automotive Industry. Adapted from [1]

\begin{tabular}{cccc}
\hline \multirow{2}{*}{ Period } & \multicolumn{3}{c}{ Trade Balance - Automotive Industry - US\$ million } \\
\cline { 2 - 4 } & IMPORTS & EXPORTS & BALANCE \\
\hline 2004 & 4750 & 8383 & 3633 \\
2005 & 6191 & 11442 & 5251 \\
2006 & 7150 & 12308 & 5158 \\
2007 & 10327 & 13461 & 3134 \\
2008 & 16372 & 14012 & -2360 \\
2009 & 12459 & 8318 & -4141 \\
2010 & 18247 & 12843 & -5404 \\
2011 & 24301 & 16230 & -8071 \\
\hline
\end{tabular}

V. Prabhu, M. Taisch, and D. Kiritsis (Eds.): APMS 2013, Part II, IFIP AICT 415, pp. 375-382, 2013.

(C) IFIP International Federation for Information Processing 2013 
The main targets of the program are: create favorable conditions of competitiveness to companies produce cleaner and safer vehicles; invest in the local supply chain through suppliers enablement and in product and industrial engineering and incrementing actions of R\&D local [2] [3].

\section{Objectives}

The objective of this paper is to present the opportunities, the challenges and the counterparts deriving of the creation of the program "Inovar-Auto" of the Brazilian federal government, in force to the period between 2013 and 2017.

Besides, having an understanding of the necessary outlays and investments, demanded to suit the goals of the program.

\section{Methodology}

The methodology applied for this research is exploratory, based in bibliographic review and secondary data collected through the information obtained among the Inovar-Auto decree, ANFAVEA (National Association of Auto-motor Vehicles Producer) and its annual report; OICA (Organization of Motor Vehicle Manufacturers); MDIC (Ministry of Development, Industry and Foreign Trade) constitute the basis for this study.

\section{$4 \quad$ Results and Discussion}

Through the analysis of the content of the decree number 7819 published in 3rd of October 2012, shall be deemed to be enabled companies that produce, in the country, motorized vehicles; companies that do not produce, but commercialize in the country such products; companies that have approved investment plan to install factories; or to the ones that are already installed that have approved investment plan to create new plants or industrial projects to produce new models [2] [3].

According to [3], the habilitation to the program shall be requested to MDIC and shall be granted jointly by the Minister of Development, Industry \& Foreign Trade and the Minister of Science, Technology and Innovation. Its validity is for a period of 12 months and may be requested the extension to another 12 months, at the end of each period and limited to $31^{\text {st }}$ of December of 2017.

The general conditions to the habilitation are: regularity with respect to federal taxes; commitment of the applicant company to achieve minimum levels of energy efficiency [3].

The specific conditions describes necessary actions for each case of habilitation, like described: companies that produce, in the country, motorized vehicles; companies that do not produce, but commercialize in the country such products; companies that have approved investment plan to install factories; or to the ones that are already 
installed that have approved investment plan to create new plants or industrial projects to produce new models [3].

Companies that have approved investment plan to install factories or the ones that plan to create complementary or new plants shall observe that the habilitation will be specific and issued to each factory, plant, or industrial project that is intent to be installed. Always, observing the condition that the license is valid for 12 months. In this case, the extension is only permitted to another 12 months, provided that in compliance to the plans of installation and capital expenditure. Finally, the investment plan shall contemplate the technical descriptions of the vehicles to be imported and produced [3].

The habilitation of the brands that do not produce, but commercialize vehicles in the country is conditioned to the company's commitment in comply with the requisites described in the Table 4, Table 5 and Table 6 of this paper.

Automakers that install production plants after 2013 will have to follow the targets related to local production and minimum amount of manufacturing processes; outlays in engineering and $\mathrm{R} \& \mathrm{D}$; and energy efficiency. The targets are respectively described in Tables 2, 3, 4, 5 and 6. The compliance to the goals of the program that are related to the year 2013 shall be postponed to first calendar-year of the habilitation; the targets for 2014 in the second calendar-year of the homologation, consecutively until 2017 [3].

To the companies that are already installed in Brazil, the main condition to the license shall be subjected through the company's compliance in performing locally, directly or through third parties, the minimum amount of manufacturing activities, infrastructure and engineering, according Table 2 of the processes listed in the Table 3 , in at least eighty percent of vehicles manufactured.

Table 2. Minimum amount of manufacturing activities to be locally performed.Adapt from [3]

\begin{tabular}{cccc}
\hline Period & \multicolumn{3}{c}{ Vehicles } \\
\cline { 2 - 4 } & $\begin{array}{c}\text { Passenger Cars and } \\
\text { Light Commercial }\end{array}$ & Trucks & $\begin{array}{c}\text { Powertrain } \\
\text { aggregated in } \\
\text { Chassis }\end{array}$ \\
\hline 2013 & 6 & 8 & 5 \\
2014 & 7 & 9 & 6 \\
2015 & 7 & 9 & 6 \\
2016 & 8 & 10 & 7 \\
2017 & 8 & 10 & 7 \\
\hline
\end{tabular}

Thereby, the Table 2 represents the number of processes, for each vehicle category, that the company must fulfill in every calendar-year, until 2017. So forth, the Table 3 lists the processes that the company shall select to fulfill the requisits of Table 2. 
Table 3. List of manufacturing process required per vehicle category. Adapt from [3]

\begin{tabular}{lccc}
\hline \multicolumn{1}{c}{ Processes } & Vehicles & \\
\cline { 2 - 4 } & $\begin{array}{c}\text { Passenger } \\
\text { Cars and } \\
\text { Light } \\
\text { Commercial }\end{array}$ & Trucks & $\begin{array}{c}\text { Powertrain } \\
\text { aggregated } \\
\text { in Chassis }\end{array}$ \\
\hline Stamping & $\mathrm{X}$ & $\mathrm{X}$ & \\
Welding & $\mathrm{X}$ & $\mathrm{X}$ & $\mathrm{X}$ \\
Corrosion treatment and painting & $\mathrm{X}$ & $\mathrm{X}$ & $\mathrm{X}$ \\
Injection of Thermoplastics & $\mathrm{X}$ & $\mathrm{X}$ & $\mathrm{X}$ \\
engine manufacturing & $\mathrm{X}$ & $\mathrm{X}$ & $\mathrm{X}$ \\
Manufacture of gearbox and transmission & $\mathrm{X}$ & $\mathrm{X}$ & $\mathrm{X}$ \\
Assembly of steering and suspension systems & $\mathrm{X}$ & $\mathrm{X}$ & $\mathrm{X}$ \\
Assembly of electrical system & $\mathrm{X}$ & $\mathrm{X}$ & $\mathrm{X}$ \\
$\begin{array}{l}\text { Assembly of brake system and axles } \\
\text { Assembly, final check and compliant trials }\end{array}$ & $\mathrm{X}$ & $\mathrm{X}$ & $\mathrm{X}$ \\
Laboratory for development and tests of & & $\mathrm{X}$ & $\mathrm{X}$ \\
products & $\mathrm{X}$ & $\mathrm{X}$ & $\mathrm{X}$ \\
Chassis and cabin assemblage & & $\mathrm{X}$ & $\mathrm{X}$ \\
$\begin{array}{l}\text { Monobloc production or chassis assemblage } \\
\text { Final assemblage of cabins with installation }\end{array}$ & $\mathrm{X}$ & & \\
of finishing acoustic and thermic items & & $\mathrm{X}$ & \\
$\begin{array}{l}\text { Body production preponderantly through } \\
\text { parts stamping regionally }\end{array}$ & & $\mathrm{X}$ & \\
\hline
\end{tabular}

Additionally, the companies that are already installed in Brazil must meet at least two of the following requisites:

1- Accomplish, locally, minimum outlays in R\&D corresponding to the company's revenue, according to the following schedule in Table 4:

Table 4. Minimum outlays in R\&D required to fulfill requisites of Inovar-Auto program (based in company's turnover). Adapt from [3]

\begin{tabular}{cc}
\hline Period & $\begin{array}{c}\text { Outlays in R\&D based in com- } \\
\text { pany's turnover }\end{array}$ \\
\cline { 2 - 2 } & Percentage \\
\hline 2013 & $0,15 \%$ \\
2014 & $0,30 \%$ \\
2015 & $0,50 \%$ \\
2016 & $0,50 \%$ \\
2017 & $0,50 \%$ \\
\hline
\end{tabular}


2- Perform, locally, minimum outlays in engineering, industrial technology and capacitation of suppliers that correspond to a percentage of firm revenue, according to the following schedule in Table 5:

Table 5. Outlays in engineering, industrial technology and suppliers enablement required to fulfill requisites of Inovar-Auto program (based in company's turnover). Adapt from [3].

\begin{tabular}{cc}
\hline Period & $\begin{array}{c}\text { Outlays in engineering based } \\
\text { in company's turnover }\end{array}$ \\
\cline { 2 - 2 } & Percentage \\
\hline 2013 & $0,50 \%$ \\
2014 & $0,75 \%$ \\
2015 & $1,00 \%$ \\
2016 & $1,00 \%$ \\
2017 & $1,00 \%$ \\
\hline
\end{tabular}

Note that the expenditures related to R\&D and engineering described in the Table 4 and Table 5 shall be performed either directly; or via a contractor; finally, through universities; institutions of research; companies that has a determined specialization and independent inventors.

3- Adhere to the program of energy efficiency and carbon emission labeling determined by MDIC to be controlled by INMETRO (National Institute of Metrology, Quality and Technology), with a percentage of products according to the schedule in Table 6.

Table 6. Volume of products to be adhered to the program of energy efficiency and carbon emission labeling. Adapt from [3]

\begin{tabular}{cc}
\hline Period & $\begin{array}{c}\text { Minimum amount of products } \\
\text { adhering emission labeling }\end{array}$ \\
\cline { 2 - 2 } & Percentage \\
\hline 2013 & $36 \%$ \\
2014 & $49 \%$ \\
2015 & $64 \%$ \\
2016 & $81 \%$ \\
2017 & $100 \%$ \\
\hline
\end{tabular}

The adhesion to the program of energy efficiency and carbon emission labeling, the applicant company must fulfill levels of energy efficiency and autonomy expressed in kilometers per liter $(\mathrm{Km} / \mathrm{L})$, or in energy consumption expressed in 
mega-joules per kilometer $(\mathrm{MJ} / \mathrm{Km})$. Measurements and instrumentation procedures must be according to the standard ABNT NBR 7024:2010 [3] [4].

In order to fulfill the requisites of the program Inovar-Auto, the applicant company should be able to achieve until $1^{\text {st }}$ of October 2017 levels of energy consumption not higher than the following equation:

$$
\mathrm{CE}_{1}=1,155+0,000593 \times \mathrm{M}_{\text {applicant }}
$$

CE1: Energy consumption limit to apply for the program Inovar-Auto.

$\mathrm{M}_{\text {applicant }}$ : average weight in $\mathrm{Kg}$ per gear of the all vehicles sold by the company weighted by the number of vehicles sold in the 12 months prior [3] [4].

The application to the program Inovar-Auto and the compliance to its requisites will ensure a tax relief up to $30 \%$. The benefit will be applied as presumed credit in the IPI (tax over industrial production) and it will be calculated by multiplying the coefficients presented in Table 7 with the values of the expenditures made with strategic supplies and tool-shop, defined in the Table 3.

Table 7. Coefficient applicable over expenditures with strategic supplies and tool-shop [3]

\begin{tabular}{cc}
\hline Period & $\begin{array}{c}\text { Presumed credit } \\
\text { coefficient to be applied }\end{array}$ \\
\cline { 2 - 2 } & Coefficient \\
\hline 2013 & 1,30 \\
2014 & 1,25 \\
2015 & 1,15 \\
2016 & 1,10 \\
2017 & 1,00 \\
\hline
\end{tabular}

From $1^{\text {st }}$ of January 2017 until $31^{\text {st }}$ of December 2020 the companies will be entitled to have IPI relief of $1 \%$ or $2 \%$ according to the levels of energy efficiency achieved.

The following equation describes the level of energy efficiency to be achieved until $1^{\text {st }}$ of October 2016, in order to have an IPI relief of $2 \%$, from $1^{\text {st }}$ of January 2017 to $31^{\text {st }}$ of December 2020:

$$
\mathrm{CE}_{1}=1,067+0,000593 \times \mathrm{M}_{\text {applicant }}
$$

The next equation describes the level of energy efficiency to be achieved until $1^{\text {st }}$ of October 2016, in order to have an IPI relief of $1 \%$, from $1^{\text {st }}$ of January 2017 to $31^{\text {st }}$ of December 2020:

$$
\mathrm{CE}_{1}=1,111+0,000593 \times \mathrm{M}_{\text {applicant }}
$$




\section{Conclusion}

In summary, with the introduction of the new program, Brazilian authorities uplifted by $30 \%$ the IPI of all vehicles commercialized in Brazil. In the other hand, companies that stay in compliance to the Inovar-Auto requisites will be able to have a tax benefit in equal percentage, during the period of the program duration, which means, 1 st of January 2013 until 31st of December 2017. From 1st of January of 2017, add up the incentives related to the energy efficiency that can elevate the benefit in $1 \%$ or $2 \%$.

However, from $1^{\text {st }}$ of January 2018, the IPI burden will be reduced to prior levels and the only tax incentive, from that, will be granted based in the energy efficiency.

Historically, concerns in Brazil, as well as in other developing countries, have been in how to boost its industry through more innovative and competitive products has been focus of governmental actions in favor of technological development combined to industrial applications. It is in according with [5] [6] [7] [8].

It should be taking into account the Schumpeterian vision that economic growth and trade performance are normally related to activities in industries of technology intensive [5] [9].

The understanding of this research is aligned with [9], ergo, in a country, where the automotive industry is constituted in majority by foreign multi-national companies, the program Inovar-Auto seeks to attack the lack of continuity and long-term commitment due to political and economic issues that has been one of the main obstacles the country to sustain its industrial development.

The results of the new program are still uncertain, once, its requisites create barriers in opposition to the free trade. Nevertheless, the internal market is significant and this can be observed in a surveying from [10] that appoints to investments around USD 33 billion until 2017 to meet the requisites of the new legislation, which, nearly USD 24 billion are the investments in course or forecasted by vehicle manufacturers and USD 9 billion by the system and auto-parts manufacturers.

The condition that stipulates minimum amount of expenditures with R\&D and engineering, gives the opportunity to do it directly or through third parties. The initiative indicates a potential problem related to engineering resources, presented in [2]. The indication derives from the fact that the sector revenue and extrapolated revenue to the next years until 2017. The volume increase that is objective of the program and estimations from [1] and [10] appoint to investments in engineering and R\&D around USD 14 billion.

Another important issue is energy efficiency, and its definition is according to [12], which means, the rationalization of energy and it is based on the laws of thermodynamics. Energy efficiency includes the set of actions of rationalization, leading to the reduction of energy consumption without loss of quantity or quality of goods and services produced, or the comfort provided by energy systems used. Thus, one can say that energy efficiency is an activity that seeks to optimize the use of energy sources. So, in line with [13], both, energy efficiency as renewable energy are considered the two pillars of sustainable energy policy. 
With the implementation of Inovar-Auto, automakers will be entitled to benefits such in the case of achieving energy efficiency levels, for example, vehicles of the new system will have to consume, by $2017,12 \%$ less fuel than current products.

Through the data obtained from [13], the paper concludes that the energy efficiency requisites are still shy and not aligned with the requisites of countries that are integrating the group of the biggest world car markets, who have already adopted mandatory energy efficiency measures for at least three decades.

\section{References}

1. ANFAVEA. Brazilian Automotive Yearbook 2012. ANFAVEA (2012), http: / / www . anfavea.com.br/anuario.html

2. Perrotta, R., Vendrametto, O.: Development of engineering competencies in brazil and innovation policies, an overview of the automotive sector. In: Emmanouilidis, C., Taisch, M., Kiritsis, D. (eds.) APMS 2012, Part II. IFIP AICT, vol. 397, pp. 716-723. Springer, Heidelberg (2013)

3. BRASIL, República Federativa. Diário Oficial da União - DECRETO No 7.819, DE 3 DE OUTUBRO DE 2012. Imprensa Nacional (2012) ISSN 1677-7042

4. ABNT. ABNT NBR 7024:2010, Light road vehicles - Fuel consumption determination Test method. ABNT (2010)

5. Pereira, L., Plonski, G.A.: Shedding light on technological development in Brazil. Technovation 29(6-7), 451-464 (2009)

6. De Negri, J.A., Salerno, M.S.: Inovações, Padrões Tecnológicos e Desempenho das Firmas Industriais Brasileiras. IPEA (2005)

7. Kannebley Jr., S., Porto, G.S., Pazello, E.T.: Characteristics of Brazilian innovative firms: an empirical analysis. Research Policy 34(7), 872-893 (2005)

8. Wang, T.Y., Chien, S.C.: The influences of technology development on economic performance-the example of ASEAN countries. Technovation 27(8), 471-488 (2007)

9. Amsden, A.H.: Import substitution in high-tech industries: Prebisch lives in Asia. Cepal Review 82, 75-89 (2004)

10. Franco, C.: Aposta no Inovar-Auto. Revista Automotive Business, 19th edn., p. 36 (2013)

11. Riato, G., Kutney, P.: Empresas estão despreparadas para o Inovar-Auto. Automotive Business Magazine (2013), http://www.automotivebusiness.com.br/noticia/ 16082 / empresas-estao-despreparadas-para-o-inovarauto, $\% 20$ acessado\%20 em\%2 0 mar\%C $3 \% A 70 \% 202013$

12. Godoi, J.M.A., Oliveira Júnior, S.: Gestão da eficiência energética. In: 2nd International Workshop Advances in Cleaner Production (2009),

http: / / www . advancesincleanerproduction. net/second/files/ sessoes/5a/1/J. $\% 20$ M. $\% 20$ A. $\% 20$ Godoi $\% 20-\% 20$ Resumo 20 Exp.pdf

13. Portal Brasileiro de Energias Renováveis, http: / /www . energiarenovavel .org/ index .php?option=com_content\&task=view\&id=17\&Itemid=306 